\title{
Responsibility Accounting: An Overview
}

\author{
Atu,Omimi-Ejoor Osaretin Kingsley; Ogbeide Endurance; \\ Agbo Innocent Sunny; Clement E .Ozele \\ (Aca,Fcma,Acti,Aat, M.Sc(Accounting), M.Sc(Business), Mba(Accounting)Pdg (Comp.Sc); Dipl.Ph.D In View) \\ Lecturer - Department Of Accounting Igbinedion University, Okada. Edo State, Nigeria-West Africa. \\ (B.Sc, M.Sc Mnim) Audit Manager, Atu, Omimi-Ejoor Osaretin \& Co.(Chartered Accountants) \\ Urubi Street, Iyaro P.O. Box, 9006 Benin City. Edo State, Nigeria-West Africa. \\ ( B.Sc, Mbf, Cna, Acma) Lecturer - Department Of Accounting Igbinedion University, Okada. Edo State, \\ Nigeria-West Africa. \\ (B.Sc, M.Sc, Can) Lecturer - Department Of Accounting Igbinedion University, Okada. Edo State, Nigeria-West \\ Africa.
}

\begin{abstract}
This paper is focus on responsibility accounting: issues and effect of transfer pricing on the Nigeria economy. The definition of responsibility accounting by different authors where given followed by the various responsibility which are the cost, revenue and investment centers. Detailed analysis was made on transfer pricing which is now becoming a global issue. This is as a result of several activities engaged in by multinational firms to reduce their corporate tax burden. A conceptual approach was taken at reviewing several literatures to identify the methods and effect of transfer pricing on the economy. Also several recommendations were made to aid the transfer pricing policy in Nigeria.
\end{abstract}

\section{Introduction}

Organizations due to growth sometimes decentralize their activities. This decentralization may be within the country of their domain or across the boarders of their domain. These types of set-up have their own advantages and disadvantages, while it may be possible for a single proprietor to monitor and oversee the detailed operations of a small business outfit it may be impossible for the individual to oversee all the operations of a large scale organization and take all the relevant decisions required.

In view of the above, it becomes necessary to transfer some management functions to subordinate managers leading to some form of decentralization.

Decentralization is defined as a system in which the authority for decision making is delegated to other levels of management. This is other wise known as divisionalisation. It is the division of a business into autonomous regions or product business. Each division has its own revenue which might be a subsidiary company under the head office or profit centre/investment centre within a single company. In practice, it's impossible to have either a completely centralized organization or a completely decentralized organization. In effect, decentralization is a matter of degree along a continuum. It must be noted that decentralization is more evident in profit-seeking organizations then in non-profit organizations.

\subsection{EFFECTS OF DECENTRALISATION ON PLANNING AND CONTROL}

In analysing the effect of decentralization, we tend to look at the changes that decentralization has brought in relation to planning and control in an organizational setup which includes:

1. Senior management is relieved from trivial matters leaving them with more time for overall review.

2. Speed in operational decisions as the manager at the division swiftly reacts to changing local circumstances.

3. Provision of better training ground to junior staff who aspire to be at the topmost level of the organization.

4. Encourage initiatives and motivates managers

5. Increases flexibility and reduces communication gap.

6. Encourages sub-optimal decision making.

7. Friction between divisional managers, particularly where the performance of one division is dependent on another

8. Duplication of services which may be less expensive when centralized.

9. Frequent rise in cost of accumulating and processing information.

10. Encourages narrow mindedness in that a divisional manager only knows what is going on in his division.

11. Apportionment of overhead cost into individual profit centers.

12. Introduction of appropriate recording and measuring procedures

13. Determination of the form, content and effective basis for the preparation of budget at different level of management. 
However, in the decentralization of planning and control top management often retains some control and decisions while others are delegated. Some of the decisions, planning and controls retained by top management are:

- $\quad$ Appointment of senior staff

- $\quad$ Determination of corporate objectives of the organization

- $\quad$ Approval for all major capital expenditure proposals

- $\quad$ Product line closure and departmental closure decisions.

- $\quad$ Monitoring of over all results and settling interdepartmental deputes.

- $\quad$ Centralized services such as legal services

- $\quad$ Decision relating to sourcing of funds and investment of surplus funds.

\section{Responsibility Accounting}

Responsibility accounting as defined by (CIMA) is a system of accounting that segregates revenue and costs into areas of personal responsibility in order to asses the performance attained by persons to whom authority has been assigned. Responsibility accounting can also be referred to as activity accounting. It is used to measures evaluate and monitor decentralization process.

Responsibility accounting aims to provide accounting reports. This enables every manager to be aware of all the items, which are within his area of authority. Hence, as a system of accounting it distinguished between controllable and uncontrollable cost.

With Responsibility accounting, it is possible to identify or recognize decision centre within an organization for the purpose of tracing costs to the individual managers who are charged with the responsibility of making decisions about costs and revenue in an organization.

Within the concept of divisional performance evaluation, there are three types of responsibility centers which can also be referred to as Responsibility accounting units, this are cost centre, profit centre and investment centre.

\subsection{RESPONSIBILITY CENTRES}

1. Cost Centre:

A cost centre is defined as a location, function, department or section in respect of which costs may be ascertained and related to cost units for control purpose only. Cost centre form the basis for building up cost records for cost measurement, budgeting and control. Managers of functional departments might be treated as cost centers and made responsible for their costs e.g., maintenance division is measured by variance analysis.

\section{Profit Centre:}

A profit centre is any sub-unit of any organization which is responsible for revenue, cost and profit. It is a unit to which both revenue and cost are assigned, such that the profitability of the sub unit can be measured. The following conditions must exist before the adoption of profit centers:

(a) There must be a unit of the organization to which both revenue and costs can be separately attributed

(b) The revenue might come from external sources through sales of goods or services or from internal work done for other profit centers for which transfer price can be charged.

(c) There should be sufficient decentralization of authority within the company to permit profit centre managers to make decisions about selling prices (including transfer prices) and output levels at those prices.

\section{Investment Centre:}

It is a unit of an organization where a divisional manager is allowed to exercise some discretion about the amount of investment undertaken by the division. In assessing the result of the centre, the profit earned must be related to the amount of capital invested. Performance here is measured by return on capital employed (ROLE) otherwise referred to as return on investment (ROI)

The following conditions must exist before a centre is adopted as an investment centre.

(a) The centre must make use of assets which can be separately attributed to it.

(b) The centre must make use of assets which the centre manager has control over in terms of new investment decision asset replacement decision. etc.

(c) All the conditions listed under profit centre above.

\subsection{CHARACTERISTICS OF COST, PROFIT AND INVESTMENT CENTRES}

(a) Cost centre manager has control over controllable cost items.

(b) Profit centre manager has control over costs, sales price and output volumes and is made accountable and responsible for the profit achieved. 
(c) Investment centre manager has control over costs, sales price, output volumes and investment in fixed and current assets.

\subsection{ANALYSIS OF COST, PROFIT AND INVESTMENT CENTRES}

The cost centre relates to the ascertainment of costs for control purposes and it forms the basis for building up cost in details.

Profit centre is responsible for revenue, cost and profit. In other words, it is a unit to which both revenue and cost are assigned. The manager of the profit centre has a responsibility of maximizing revenue by focusing on recurrent expenditure. Performance and usually measured by volume of profit.

Investment centre as defined by CIMA is a profit centre in which inputs are measured in terms of expenses and output are measured in terms of revenues and in which assets employed are also measured. The excess of revenue over expenditure is related to assets employed.

\section{Concept Of Transfer Pricing}

The term transfer pricing has been defined variously by different authors. Okoye (1997), in his own view, defines transfer price as "a price used to measure the value of goods or services furnished by one division to another division within a company". Adendiji (2005) defines it as "the monetary value attached to goods manufactured by a particular decision making unit and then transferred to another division for the purpose of being utilized for the divisional final product". While Dean, Feucht and Smith (2008), are of the view that it is "pricing of goods and services that are transferred between members of corporate family including parent to subsidiary, subsidiary to parent and between subsidiaries.

Transfer pricing as defined by (CIMA) is a price related to goods or other services transferred from one process or department to another or from one member of a group to another.

Transfer pricing is necessary in order to appraise the separate performance of the divisions or departments, it is used to evaluate the revenue accruing to the selling division and the cost or expenses incurred by the buying division.

The general concern of transfer pricing is all about the (i) impact on divisional performance, (ii) impact on firm- wide profits and (iii) impact on divisional autonomy.

\subsection{OBJECTIVES OF TRANSFER PRCING SYSTEM}

The main objectives of transfer pricing policy satisfy the following broad criteria.

1. Goal Congruency

The transfer pricing system of an organization should encourage each division to take decisions which are not only beneficial to the division but also beneficial to the whole organization. The transfer pricing policy must not encourage sub-optimal decision making. Sub-optimality is the maximization of divisional goals to the detriment of corporate goals.

\section{Performance Evaluation}

The transfer pricing should be such that would enable central management to effectively determine the contribution of each of the division towards corporate profit. This would enable reliable assessment to be made of divisional performance.

\section{Autonomy}

The transfer price should seek to maintain the maximum divisional autonomy so that the benefit of decentralization is achieved. The profit of one division should not be dependent on the action of other divisions. In establishing a transfer price, which is peculiar to all divisionalised organizations where the activities are segmented into autonomous units and a great deal of authority delegated to the divisional heads, it is necessary to note that no one method of transfer pricing is suitable in all cases. The transfer price method to be adopted depends on management policy at the given point in time. The optimum transfer price is the opportunity cost to the entire organization and not necessarily the opportunity cost to either of the divisions buying or selling the products or services.

\subsection{METHODS OF TRANSFER PRICING}

There are many ways of establishing transfer price, this includes:

\section{Cost Based Transfer Pricing Method}

According to Aruomoaghe \& Atu (2010) the Cost based method, transfer price is equal to the unit cost of production to the selling and responsibility centre department. Cost could wither be variable, standard or total cost. This method is good for its simplicity in getting cost information. The cost based method has its advantage and they include: It assists in measuring production efficiency by comparing actual cost with budgeted cost, The transfer pricing could be fixed and agreed in advance without being subject to external function and It's useful in decision making analysis especially with the use of marginal cost approach. It however has some drawback 
and they include: Lack of cost control by the selling division since the actual cost of production is used as transfer price, unless standard costs are used, month by month fluctuations will continue to occur and Profitability of the autonomous divisions cannot be effectively measured as revenues are completely ignored.

\section{Market Based Transfer Pricing Method}

Is simply the price at which the goods and services are offered at the open market. It is recommended for economic evaluation performance and where different buyer and seller exists This approach to transfer pricing is used where management policy grants autonomy to the buying and selling divisions to buy or sell the goods or services internally or externally. There are some disadvantages in using this method and they include to mention a few: There is goal congruence as any division taken by the divisional management using market based transfer pricing method would not only be in the interest of the division alone but also that of the whole organisation as well, Divisional autonomy is maintained and It is mot adequate for measuring performance and motivating managers.

However, there are also some drawbacks to using a transfer price based on market price and they include: there may be problem if this goods transffered donot have already market price. Also, in today regulated economy, perfectly competitive markets are very rare and that can affect the market price rendering it inapplicable as an effective price.

Furthermore, there is no guarantee that the market price of a product is strictly comparable in terms of grade and other relevant characteristics and a situation may arise in which the market price is a distress price Adediran, (2006).

\section{Negotiated Transfer Pricing Method}

Under this method, the selling division and the buying division agree in advance to use a mutually acceptable transfer price. In other words negiotiated transfer price as Described by Aruomoaghe \& Atu (2010) is the transfer price established by agreement between the supplying and receiving responsibility centers for their mutual benefit. This system is considered well enough for performance evaluation purpose if both parties have equal bargaining power.

This is appropriate if it would be assumed that such negotiations would result in decisions which are in the interest of the company as a whole and which are acceptable to the divisions concerned. This method also has its benefit and drawbacks. Amongst the benefit to mention a few are: There is less disputes on the transfer price fixed because many factors would have been effectively considered, Performance evaluation by central management will be devoid of any disputed on the part of the divisional managers and It gives divisional managers high degree of control and involvement when prices are set.

It drawbacks include; Negotiation may be time consuming, The negotiated price may be influenced by the negotiating ability, personality and fluency of the managers involved and The corporate interest may be subordinated to individual divisional interest.

Other types of transfer price include the following:

\section{Arbitrary Transfer Pricing Method}

Under this method, the transfer price is centrally based on what top management conceived to be most beneficial to the company as a whole. Individual managers may have some say but no control over the price set.

\section{Dual Transfer Pricing System}

It is instructive to note that no single transfer pricing method is capable to satisfying the three broad objectives of transfer pricing. Infact, it is just not possible to have a single transfer price. The buying division and the selling division have different interests in the transfer price.

In a dual pricing system, the buying division is charged a hypothetical market price while the selling division is given credit for full cost plus a normal mark-up. The income for the company as a whole will be less than the total income for the divisions. The dual transfer pricing system is to tackle the area of difficulties in the application of the various bases of pricing a firm's products or services.

However, it has been established that only dual transfer pricing system is capable of promoting goal congruence, motivation, autonomy and performance evaluation under all conditions.

According to Horngren, (1996), as cited by Adediran (2006), "The most popular method around the world are the market price and cost based price. Some authors are of the view e.g. (Adediran 2006), that organizations can be at optimal situation and enjoy great advantages by employing a "Dual price".

\section{International / Multinational Dimensions Of Transfer Pricing}

With the advent of multinational corporations and their continued growth, they have added another more complicated dimension to transfer pricing. 
In setting an international transfer price, a company will usually concentrate on satisfying a single objective i.e. minimize income taxation. The other broad objectives of transfer pricing are considered secondary. By minimizing income taxes through the use of transfer pricing, the company's profit after tax will increase. It should be noted that national tax authorities of countries involved (that is, the home country of the multinational corporation and the host country) are now taking a very close look at whether the international transfer price constitutes an "arm's length price" that is the price the two parties would have agreed to, if they had not been related.

Muellar et al (1991), as cited by Omoye \& Okafor (2004) classifies objectives of MNC International Transfer pricing as: Minimization of worldwide income tax, import duties, financial restriction avoidance, currency fluctuation management and winning support approval of host countries. Worldwide income tax minimization could be achieved by setting high transfer prices for goods and services entering the country with a high tax and low transfer prices for countries with low tax rate. The result is that the recipient countries with high tax rate will have high cost of goods sold and low profit and hence low corporation income tax for the recipient unit country. Since some profit have already be reserved in units countries with low tax rate the total profit of the MNC would be high but tax liability would be low.

Worldwide import duties minimization: Import duties are normally based on the values of goods and services (advalorem tax). When goods with high value are under valued and transferred at low price, the resulting tariffs will be lower. MNCs could use his transfer pricing strategy to send goops to subsidiaries where there is import restriction through high tariff in the host country of the subsidiaries. By using low transfer price, a subsidiary may be able to import a large quantity of goods and services at very low tariff.

Avoidance of financial restrictions: IT is not uncommon for government of host countries to place economic or financial restrictions on MNCs operations. MNCs more often than not circumvent this restriction through transfer pricing. If for example a country restricts the amount of cash that is legally allowed to leave its boundaries in form of dividend payment, by using a high transfer price on goods imported into the country; MNCs would move more cash from subsidiaries companies. This is possible because the importing subsidiaries must remit payment. Similarly, financial restriction on MNCs could be mitigated when the "home countries" of the MNC allow a tax credit or subsidy on the value of goods and services exported. In this regard, high transfer price on export allows for a larger subsidy thereby reducing the corresponding tax liabilities. Currency fluctuations management: When foreign subsidiary countries devalue it's currency to address balance of payments problem resulting from inflationary environment, a high transfer price could be used to counter the effect such devaluation will have on its monetary asset. During inflationary period, the purchasing power of monetary asset is eroded. Therefore, using inflated high transfer price on good and services to subsidiaries in countries with inflation will facilitate timely cash removal.

Winning the support and approval of host countries' government: The activities of MNCs in respect of manipulation of transfer prices to the detriment of host countries have not been unnoticed. As a result of the tax implication, government of host countries are more concerned about transfer pricing related transactions. It therefore means that MNCs must co-operate with governments by not frequently changing or manipulating transfer price to its advantages. This is necessary to maintain goodwill from the host country.

Transfer pricing seems to be more beneficial to MNCs than to the host countries of their units. Dean at al (2008:) are of the view that MNCs will continue to engage in MNC transfer pricing because of the several economic benefits. According to them, "transfer pricing assists MNCs in evaluating the financial performance of different parts of the company. Also, it may help reduce their consolidated company's tax burden".

\subsection{THE EFFECT OF MNCS TRANSFER PRICING ON THE ECONOMY}

Tax authorities and government official all over the world pay close attention to taxes paid by foreign corporations operating within their boundaries. Adediran (2006), cites how, in 1993, the US Internal Revenue Service (IRS), investigated and concluded that Nissan Motor company had minimized US taxes by setting transfer prices on passenger cars and trucks imported from Japan at unrealistically high levels. Eventually, Nissan agreed to pay the IRS, \$170 million. Also, I May 1994, Japan's national Tax Agency (NTA) alleged that coca-cola corporation has deliberately under recorded profits earned in Japan by charging excessive transfer prices to its local subsidiary for materials and concentrates imported. The NTA imposed taxes and penalties of $\$ 150$ million.

In Nigeria, the situation is more serious with multinational companies that usually over-invoice materials to the country. Arbitrary prices are usually used to transfer goods and services to Nigeria to increase cost and thereby reduce the profit and eventually reduce taxes to be paid. Despite the lame effort of government officials at curbing this, a substantial amount is being lost annually due to MNC transfer pricing manipulation. 
According to Adediran (2006), "No Indian companies in Nigeria have come out with meaningful profits. Instead they would be posting losses as a result of over-invoicing of the transferred goods and services". This is course is not healthy for our economy because it reduces the revenue accruable to the government. According to Baistrocchi (2006):

Transfer pricing in manipulation produces two major consequences. Firstly, it puts national tax jurisdictions under stress because it is an income shifting system that allows MNCs to maximize after-tax profits by channeling taxable income to juridciaiton with lower taxes. Secondly, it raises horizontal equity issued because it provides substantial advantage to MNCs over non-MNCs; only the former can use this type of international tax planning strategy.

The issue of transfer pricing is becoming a global problem. This led to the development of the organization for economic cooperation and development (OECD) model Tax convention on Income and Capital. The central role of the OECD is to minimize international double taxation by establishing some structural legal fiction to guide the divisions of international income tax base (Baistrocchi 2006).

The OECD is to audit MNCs transfer pricing to determine whether such transfer prices meet the Arm' Length Standard (ALS). If any organization is found defaulting, the regulating tax authority can assign an appropriate transfer price and recalculate the new liabilities (Dean et al, 2008).

The United States in their IRS code provided a section (section 482) to deal with the issue of MNC transfer pricing and determine whether it conforms to the ALS. Also, the Australian Tax Office mandates that; transfer pricing review must take place regularly to effectively monitor MNCs transfer pricing .

While a lot can be said of other countries, not much can be said of our country Nigeria. Apart from measure put in place to check the standards of goods and collection of import duties at our ports, nothings being done to checkmate the transfer prices place on some of these goods for subsidiaries of MNCs. The Federal Inland Revenue Service (FIRS) should put measure in place to conduct value for money audit on some of these goods transferred. Also, the professional associations (e.g. the Institute of Chartered Accountants of NigeriaICAN) should pay a vital role here. This they can do by educating their members auditing MNCs to carry out special audit in transfer pricing related transactions. We can not continue to accept that we must borrow to finance budget deficits when millions of naira are manipulatively carted away under the auspices of transfer pricking. We must wakeup to the challenge like other countries and come up with a reasonable policy to rightfully take what belong to the nation in form of adequately assessed corporate tax.

\subsection{ARM'S LENGTH PRINCIPLE}

ARM'S length principle" of transfer pricing states that the amount charged by one related party to another for a given product must be the same as if the parties were not related. An arm's-length price for a transaction is therefore what the price of that transaction would be no the open market. For commodities, determining the arm's-length price can sometimes be as simple a matter as looking up comparable pricing from non-related party transactions, but when dealing with proprietary goods and service or intangibles, arriving at an arm's length price can be a much more complicated matter.

According to Onyeukue (2009), the key principle of transfer pricing is based on the arm's length rule. This being that pricing terms between related party in the exchange of goods and services should achieved same result as if parties are unrelated. The essence of this requirement is that the quantum of profit which ordinarily should be subjected to domestic tax does not becomes a gain to another country to which profit is shifted.

\subsection{MULTI-DISCIPLINARY NATURE OF TRANSFER PRICING}

It is interesting to note that the subject of transfer pricing has adverse applications. Apart from the accounting aspect, transfer pricing has socio-economic political and even security implications as applied by multi-national companies. It could be said that transfer pricing policies have been effectively used to defend the economic and political interest of some countries to the advantages of others through the activities of multinational companies

Transfer Pricing as seen in the United States, has become an important area of enforcement for states to protect their tax revenue. The states are not always content with proposing adjustments to state taxable income only. Rather in some instances, states have sought to adjust federal taxable income for state purpose, thereby increasing the amount of income that can be taxed by the state.

\section{Summary And Conclusion}

An individual cannot oversee all the operations of large scale establishment and at the same time take all the relevant decisions required, thus the need to delegate some management functions to subordinate managers leading to some form of decentralization that will enhance motivation communication, planning etc. 
Decentralization is not without its short coming and these include increased cost of accumulating and processing information, friction between managers, duplication of services, narrow mindedness of managers, sub-optimal decision making etc.

Performance appraisal system should promote goal congruency, provide meaningful feedback, encourage initiative and longer term view.

Responsibility accounting ensures that recognition is given to cost centers, profit centers and investment centers.

Transfer pricing is the monetary value attached to goods and services exchanged between divisions of the same organization segmented into autonomous unit and with a great deal of authority delegated to the divisional heads.

The objectives of transfer pricing are mainly those of goal congruency, performance evaluation and ensuring the independence of each division. The broad categories of the basis on which transfer pricing are based include cost, market, negotiated and arbitrary.

The dual transfer pricing system is to tackle the area of difficulties in the application of the various bases of pricing a firm's products or services.

The economy stands to benefit from transfer pricing related transactions. MNCs can not continue to milk the Nigeria economy for its sustenance because this will bring about an imbalance in the economic system. It is pertinent therefore that all and be on deck too ensure the nation gets its rightful share of revenue in form of tax from MNCs indulging in transfer pricing related transactions. Also, tax officials should know that they owe the nation a duty by ensuring that MNCs taxes are adequately assessed and remitted to the government treasury.

\subsection{RECOMMENDATIONS}

Based on the foregoing discussion, it is hereby recommended that:

- Adequate and enforceable legislation be made to curb be menace perpetrated under the game of MNCs transfer pricing.

- The FIRS should embark on periodic review of MNCs transfer pricing related transactions.

- The Nigerian Accounting Standard Board (NASB), on their part should come up with a standard on transfer pricing related transactions.

- Also the government should come out with a white paper on its transfer Pricing Policy (TPP) through any of its approved agencies

\section{References}

[1]. Adeniji A. (2005): An insight into management accounting. ( $3^{\text {rd }}$ Ed.). Value analysis consults: Lagos

[2]. Adeniji, A.A. (2008): An Insight into Management Accounting. (4 ${ }^{\text {th }}$ Ed.). Yaba Lagos.

[3]. Adediran S.A (2006): Multinational transfer pricing, International Taxation and Comparative financial report practices. A Ph.D seminar presented at Igbinedion University Okada.

[4]. Aruomoaghe .J. and Atu O. K. (2010). Multinational transfer pricing: Issues and Effects on the Nigeria Economy. The Nigerian Academic forum: a Multidisciplinary journal (19)1. Awaka: Nigeria.

[5]. Baistrocchi E. (2006): The transfer pricing problem. Tax Lawyer,(59) 4. Argentia Universidad Torcuato Di Tella, Buenos Aires

[6]. Dean M., Feicht F.j; \& Smith M. (2008): Internal auditing: January/February 2008. Taxes A and M University

[7]. Dury C. (2004): Management and Cost Accounting. (6 ${ }^{\text {th }}$ Ed).Thomas Learning, London.

[8]. Horngren, C.T., Sundem, G.L., and Stratton W.O. (1999) Introduction to Management Accounting. (11 ${ }^{\text {th }}$ Ed.).New Jersey: Prentice Hall Int'l Inc.

[9]. Lucey T. (2003): Management Accounting. ( $5^{\text {th }}$ Ed.) Thomson Learning, London.

[10]. Okoye A. E. (1997); Cost accountancy: management operational application. Benin City. United City Press.

[11]. Omoye A. \& Okafor C. (2004): Multinational Corporations transfer pricing: A

[12]. conceptual approach. BIU Journal of social and management sciences, (2) Dec. 2004

[13]. Onyechukwu, . H. (2009). Transfer pricing in the Nigeria context. Retrieved from www.work.bepress.com on $10^{\text {th }}$ December 2012.

[14]. Pandey, I.M (2004): Financial Management. ( $8^{\text {th }}$ Ed.). Vikas Publishing House PVT, Ltd New Delhi

[15]. us-kpmgwntwkpmy.com, federal Tax legislative and regulatory services group.

[16]. www. transfer pricing.com/issues involved

[17]. www.google.com/r.transfer pricing implications in u.s.a

[18]. www.accountingformanagement.com 